до $+29^{\circ}$ С. кроватку. Черезъ 2 часа жнвотное вынималось, взвьшивалось,

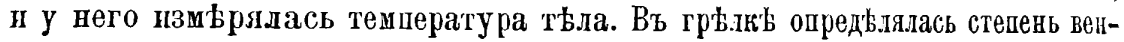
тиляціи посредсгвомъ опредъленія количества углекислоты. Вентиляпія кроватки ог єзалась не вполн' удовлетворительной (проф. H. А. Толмачевл придумаль въ этомъ отношеніи какое то улучшеніе, еще не опубликованне). Кроликъ во время пребыванія въь грьлкь учащенно дышаль, по вынутіи из' грБлки нькоторое времз ве трогаль корма, теряль въ высь (въ среднешъ 11,4 граммовъ); теміература тьла его повышалась (въ среднемъ на $1,14^{\circ} \mathrm{C}$.). На основаніи опытовъ авторъ сомньвается въ безвредности прододжительнаго употребленія грьлки для недоносковъ и полагаетъ, что она не имьеть пока по своему значенію выдающихсл препмуществъ передъ водяными ваннами. Единственное превмущество грђ.тки, это то, что за ней не требуется постоянныхъ наб.люденій, какія необходимы прп употребленіи водяныхъ ваннъ.

\title{
Н. Какушнинъ.
}

\section{A. Czempin. Hidrastinin bei Gebärmutterblutungen. (Centr. f. Gynäk.,} 1891, № 45). Гидрастининъ при маточныхъ кровотеченіяхъ.

Разбирая фармацевтическое льченіе маточныхъ кровотеченій, авторъ совершенно справедливо останавливается на прешаратах'ь спорыньи и на hydrastis canadensis, какъ на наиболье д'ьйствительныхъ средствахъ. Сиорынья дъйствуеть главнымъ образомъ на самую мышцу матки и, сльдовательно, показуется при атоническихъ кровотеченіяхъ, зависящихъ напр. отъ недостаточной посльродовой инволюціи матки, тогда какъ hydrastis оказывается всего полезв ве при такъ называемыхъ вторичныхъ кровотеченілхқ, возникающихъ подъ вліяніемъ забольванія придатковъ матки, при хроническомъ эндометрить. въ климактеритескомь періодь, у д'ввиць и т. п. Неудобство этого средства, въ формъ жидкой вытяжки, заключается въ томъ, что оно плохо дыйствуеть, будучи употреблено при наступившемъ уже кровотеченіи, и что для полученія надлежащаго әффекта оно должно быть приннмаемо за долго (недъ.ли двъ) до ожидаемої мен0-или метроррагіи.

Какъ извъстно, корень hydrastis canadensis содержить алкалоидъ гидрастилг, который путемъ окисленія можеть быть разложенъ на физіологически-недђятельную опіановуго жислоту ( $\mathrm{C}_{10} \mathrm{H}_{10} \mathrm{O}$ ) и основаніе $\left(\mathrm{C}_{11} \mathrm{H}_{13} \mathrm{NO}_{3}\right)$, получивпее названіе гидрастинина. Посльдвій и оказался собственно д'ьйствующинь нача.том средства; произведенныя $E$. Falk'омь ошыты на животныхъ показали, что гидрастининъ даеть болье значительное повышеніе кровяного давленія, чымъ гидрастинъ, и притомъ-благадаря своему дыйствію на самые сосуды, въроятно-на ихъ мышеqные элементы.

Авторъ предшриняль рядъ наблюденій на больныхъ, давая солянокислый гидрастининъ въ форм' лепешекъ: Rp. Hydrastinini hydrochlorici 0,025, Sacchari albi 1,0. M. fiat trochiscus. D. t. d. № 12. S. 4 раза въ день по 1 лепешкь. Льченіе назначалось не заблаговременно, а лишь сь появленіемъ кровотеченія, и обыкновенно 2-3 дневнаго пріема было достаточно, чтобы его остановить. Изъ 47 больныхъ у 27 терапевтическій эффекть бнль очень хоротій, у 9 -незначительный, а у 11 -отрицате.ьный. По- 
сльдній наблюдался прешмуцественно при фиброміомахь или въ очешь запущенныхъ случаяхъ. Въ общемъ же авторь вполны удовлетворенъ быстрымъ, хоти псключятельно симпгоматическпм дайствіемъ средства. А. Фишеръ.

\section{0. П. И. Архангельскій. Матеріалы нъ фармакологіи гидрастинина.} (Дисс., СЛЬ., 1891 г.; 72 сrр.).

Авторомь пронведены опыты, какь на лягушкахъ, такъ иг на теплокровных' животныхь; на первыхъ пзучено общее дыйствіе гидјастинина, а затьмь дыйствіе его на нејвную систему, на кјово- и лимфо-обращеніе; на теплокјовныхъ-же, посль ознакомленія сь обцимъ дыйствіемъ средства, пгучалось вліяніе его на кровеносную спгстелу и на матку.

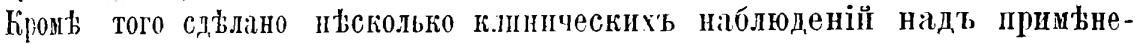
ніемъ гидрастнина вт посльроповомъ періоды, а также были попытки примьнить его прл порокахъ сердиа. Во всыхт опытахь употреблялся солянопислый гидрастпинъ Merck'il. пј)п чем's впрыскивались различной гірыпости растворы $(1 \%-20 \%)$ шли в'ь дестнллрованной водь, или въ физіологическомь растворь. Работа пгроизведена вт лабораторіи проф. И. Р. Тарханова, клиническія-же наблюдепіп дълались въ клинины

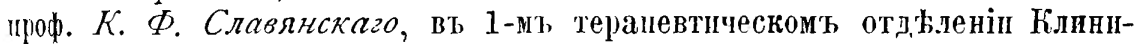
ческаго возннаго госпиталя и въ Обуховской больницы.

0тносительно дыйствія гидјастинина на лагушекь автојь приходить къ сльдуюшциљ выводамъ:

1) Малыя дозы гидрастгнина $(0,001-0,0025)$ вызываютт явленія легкаго возбужденія: лягушка дыліетея болье подвижной и легче реагирустъ па раздраженія; при этомь получается учащеніе дыханія и сердцебісній, кагъ для гровяного, такъ и для лимфатпческихъ серлециъ.

2) Вольшія дозы гидрастинива $(0,004-0,03)$ вызывають явленія обцаго угнетенія; неправильность движенія, переходящую въ параличъ; пониженіе болевой чувствительності, пјичемъ тактильная сохранена; дыханіе дывлается рьднимь и диспнопческим', затьмь наступаеть остановка сго. Сердце посль непродолжнгельнаго учащенія даеть постешенно возрастающее замедленіе, къ котороху при очень большихъ дозахъ присоединяютея неправильности вт сокращеніп отдыльных'ь его частей; остановка пропсходить въ спстоль, ова настунаеть гораздо позже (черезъ $2-3$ сутокъ) остановкі дыханія. Лимфатическія сердца останавливатотся очень рано; остановка икъ продолжается во все время двигательнаго паралича.

3) Низшая смертельная доза гидрастиннна для льтнихъ лягушекъ = $0,025-0,03$, а для зимних' $=0,015-0,02$.

4) Пониженіе болевой чувствительности вь началь дыйствія гидјастинита зависить оть пораженія периферическихт окончаній чувствительныхъ нервовъ, а позже параличь јаспространяется и на чүвствительные центры спінного мозга.

5) Разстройства движенія зависять главнымь образомъ оть угнетеніл и царалича двигательныхъ центровъ слинного мозга, чему предшествуетъ незначительное повышеніе ихъ дұлтельности; но при очень больппхъ до- 